\title{
Pengaruh Terhadap Financial Literacy, Resiko Toleransi, Kemampuan Managemen Resiko Dalam Keputusan Investasi
}

\author{
Joli Afriany ${ }^{1, *}$, Andy Hakim ${ }^{2}$ \\ ${ }^{1}$ Universitas Nahdlatul Ulama Sumatera Utara, Medan, Indonesia \\ ${ }^{2}$ STAIN Mandailing Natal, Mandailing Natal Indonesia \\ Email: 1,*joliafriani@gmail.com, ${ }^{2}$ andyhakim@stain-madina.ac.id \\ Email Penulis Korespondensi: joliafriani@gmail.com \\ Submitted: 09 Februari 2021; Accepted: 15 Februari 2021; Published: 28 Februari 2021
}

\begin{abstract}
Abstrak-Investasi merupakan kegiatan yang sangat menguntungkan jika dijalankan dengan baik dan benar berdasarkan pertimbanganpertimbangan yang tepat, tetapi melakukan investasi tidak hanya dapat berdampak baik dapat juga berdampak buruk karena kesalahan dalam melihat kemampuan terhadap perusahaan dalam menganalisa hal-hal penting yang berhubungan dengan dampak terus beroperasinya sebuah perusahaan maupun keuangan pribadi, keputusan dalam investasi tidak hanya menguntungkan juga dapat merugikan dapat diibaratkan seperti dua mata koin yang saling keterkaitan sehingga perlu diketahui beberapa faktor terhadap kemampuan perusahaan dalam financial literacy, resiko toleransi dan kemampuan managemen resiko sebuah perusahaan, setiap kriteria mempengaruhi penilaian terhadap keputusan investasi, investasi juga membantu perusahaan dalam laju operasional sebuah perusahaan dan membantu seseorang dalam menggapai tujuan hidup. Pengambilan keputusan investasi dilakukan dengan pendekatan metode pengambilan keputusan yaitu metode SAW.
\end{abstract}

Kata Kunci: Financial Literacy, Resiko Toleransi, Managemen Resiko, Keputusan Investasi, SAW

\begin{abstract}
Investing is a very profitable activity if it is carried out properly and correctly based on the right considerations, but investing can not only have a good impact it can also have a bad impact because of errors in seeing the ability of the company to analyze important things related to impact. the continued operation of a company, decisions in investment are not only profitable but can be detrimental, can be likened to two interrelated coins so it is necessary to know several factors on the company's ability in the financial literature, risk tolerance and risk management ability of a company, each criterion affects the assessment of decisions investment, investment also helps companies in the pace of operations of a company. The investment decision is made by using a decision-making approach, namely the SAW method.
\end{abstract}

Keywords: Financial Literacy, Risk Tolerance, Risk Management, Investment Decisions, SAW

\section{PENDAHULUAN}

Pasar modal merupakan gambaran terhadap alat pengukur atau gambaran kondisi perekonomian sebuah negara, pasar modal juga merupakan peranan yang sangat teramat penting dalam kegiatan ekonomi bahkan dari pasar modal dapat ditemukan informasi-informasi khusus yang diketahui oleh banyak orang atau informasi-informasi khusus dan bersifat pribadi yang ingin diketahui para orang pemodal yang biasa disebut sebagai investor, dengan perkembangan pasar modal akan mempermudah sebuah negara untuk membangun dampak positif terhadap pertumbuhan dan perkembangan perekonomian nasional, kenaikan dari pasar modal itu sendiri tidak lepas kepada adanya kenaikan terhadap jumlah investor(Gede Rudangga \& Merta Sudiarta, 2016). Perusahaan ataupun sebuah organisasi yang maju dan berkembang tidak terlepas dari adanya tangan investor baik investor asing maupun investor dalam negeri, seorang investor merupakan sebuah lembaga domestik, non domestik baik sebuah organisasi maupun perorangan yang melakukan kegiatan investasi atau sebuah modal dengan memiliki harapan terhadap pencapaian lebih dan menghasilkan laba kembali setelah proses pengolahan yang dimiliki oleh pemilik saham dengan beberapa kemampuan, investor sendiri melakukan penanaman modal yang biasa disebut dengan penamana modal baik berupa hutang yang diberikan kepada penerima modal atau dapat disebut dengan investasi ekuitas. Investor melakukan tahapan investasi ini rata-rata bertujuan untuk mendapatkan hasil atau keuntungan dalam kurun waktu jangka panjang(Robo, S., Trisno, T., Sunardi, S., \& Santosa, 2019).

Investasi merupakan stok modal sebuah perusahaan semakin banyak pihak yang melakukan investasi maka akan semakin meningkat pasar modal dan perkembangan perekonomian sehingga mengakibatkan semakin banyak keputusan yang harus dilakukan dalam pengambilan keputusan terhadap investasi, setiap sebuah pengambilan keputusan tentunya memiliki beberapa kriteria maupun faktor tertentu yang dapat mempengaruhi seorang investor dalam menangani pengambilan keputusan, dalam pengambilan keputusan sendiri terhadap investasi tentunya harus berasarkan nilai dan dasar-dasar keputusan-keputusan penting yang harus dilihat dalam managemen dan melakukan investasi dan menurut salah seorang pakar dalam pengambilan keputusan investasi, keputusan ini bersifat mutlak pribadi atau individual dan berdasarkan beberapa pertimbangan pribadi juga secara bebas dalam penerapannya(Yunita Wulan Dewi \& Sri Darma, 2019).

Adanya perkembangan teknologi yang dapat membantu dalam mengetahui informasi terhadap penanganan investasi dapat membantu seseorang investor mengetahui terhadap perkembangan kenaikan akan kebutuhan terhadpa investasi yang berdasarkan data dan asumsi public bahwasannya dengan melakukan investasi berarti menambah pundi-pundi terhadap keuangan dan tambahan pendapatan, dalam hal ini akan sangat berkaitan dengan cara seseorang atau kelompok dalam menangani literatur keuangan atau financial literacy, hal ini merupakan pengetahuan yang sangat penting dalam membantu pengetahuan dan penalaran terhadap ilmu investasi, literatur finansial itu sendiri setiap orang wajib mengetahui dan mampu 
mengolah keuangan atau finansial baik pribadi maupun sebuah organisasi karena semakin mengetahui potensi keuangan yang dapat dicapai dan dikelola dengan baik maka semakin mengetahui terhadap keuangan masing-masing yang sangat memadai atau tidak dalam melakukan investasi yang tepat hal ini juga wajib diketahui oleh seorang investor.

Untuk mengetahui literasi finansial masyarakat Indonesia juga bukan hal yang sulit karena dapat diketahui dengan bantuan teknologi dalam memperoleh informasi terhadap literatur finansial, dalam keterangan Otoritas Jasa keuangan yang biasa dikenal dengan sebutan singkatan OJK terlihat pada tahun 2019 menunjukan jumlah hasil survei nasional pada tahun 2019 terhadap indeks literasi finansialnya sebanyak 38,03\% dimana memiliki indeks inklusi finansial atau keuangan sebesar 76,19\% hal tersebut menunjukan terjadinya sediki peningkatan terhadap kenaikan keduanya dari tahun 2016. Masih sedikit perkembangan terhadap kesadaran masyarakat terhadap kemampuan terhadap pemahaan pasar modal itu sendiri yang berhubungan dengan investasi.

Dalam pengambilan keputusan juga masih sangat sering terjadi berdasarkan logika dan perasaan seseorang maupun secara rasional. Semua hal tersebut termasuk dalam pengambilan keputusan berdasarka psikologi yang bias saja dalam keadaan tertentu mengakibatkan pengambilan keputusan tidak tepat, keputusan -keputusan tersebut didukung beberapa faktor seperti herding atau kecendeungan terhadap mengikuti sebagian atau beberapa kelompok terhadap pelaku investasi. Ikut sertanya pengambillan keputusan secara psikologi manusia semata kecenderungan terhadap adanya investor yang dari asing langsung dijadikan sebagai ahli dan tidak akan gagal terhadap kemampuan menjadi investor handal dan banyak alasan lainnya yang nantinya akan berujung kepada tidak sesuai terhadap harapan yang diharapkan dan penyesalan terhadap melakukan investasi terlebih lagi jumlah investasi tersebut sangat besar hal ini biasa disebut dengan ketidakpastian dalam pencapaian terhadap keputusan investasi(Yushita, 2017).

Ketidakpastian dalam pencapaian hasil dari sebuah keputusan investasi tentunya memiliki dampak tertentu terhadap keadaan yang akan datang dimasa depan nantinya sehingga diperlukan pengetahuan terhadap risk tolerance atau resiko toleransi, resiko toleransi yang dimaksud adalah kemampuan terhadap dampak yang bias diterima dalam mengambil resiko terhadap investasi yang akan dilakukan sehingga dapat dikatakan pengambilan keputusan terhadap investasi harus memiliki kemampuan dan pengetahuan dalam menghadapi apapun yang akan terjadi baik atau buruk dalam sebuah investasi hal ini dapat dinyatakan sebagai pengaruh besar dari pengambilan keputusan investasi. Dalam sebuah investasi diperlukan pemahaman yang baik terhadap investasi dan lingkungan pasar modal maupun lingkungan pasar saham, kemampuan tersebut harus didukung dengan keadaan dan kondisi investor dalam managemen resiko(Babar, Thaheem, \& Ayub, 2017).

Managemen resiko sendiri merupakan manajemen resiko perusahaan dimana tidak hanya mengolah perihal apa yang terjadi pada investasi tetapi manajemen resiko terhadap seluruh aspek perusahaan baik, dari saingan, resiko internal dan external, strategi dan lain-lain. Upaya pengambilan keputusan investasi bukan hal yang harus diambil berdasarkan kepemilikan dana dari seorang investor Karen a banyak kemungkinan yang akan terjadi disetiap peluang keberhasilan maupun kegagalan yang akan terjadi kedepannya, pengambilan keputusan tidak boleh dilakukan secara tergesa-gesa berdasarkan kemauan dan psikologi seseorang tetapi dibutuhkan pengetahuan terhadap beberapa faktor penting sebagai pendukung, perlu dilakukan perhitngan terhadap keseluruhan faktor dalam mempengaruhi tingkat kematangan terhadap faktor lainnya untuk memperkuat pengambilan keputusan investasi(Bellini \& Di Bernardino, 2017).

Dari keseluruhan data yang dimiliki setiap pengambilan keputusan investasi digunakan pendekatan metode terhadap keputusan investasi untuk melihat seberapa besar dari keseluruhan aspek faktor maupun kriteria dalam kekuatan dan keyakinan terhadap keputusan investasi dengan menggunakan metode SAW yaitu singkatan dari Simple Additive Weighting dimanan metode ini merupakan metode paling mudah dalam melihat relasi antara satu krteria dengann kriteria lainnya(Yunaldi, 2019). untuk mendapatkan hasil yang nyata dan sesuai dengan data dan tidak berdasarkan kepentingan pribadi semata dalam pengambilan keputusan investasi, hal ini dianggap lebih relefan dan tersistem sehingga memungkinkan terjadi sedikit persenan kesalahan terhadap pengambilan keputusan investasi, penggunaan metode ini sudah banyak diterapkan di dalam pengambilan keputusan yang bersifat sangat penting seperti pada penelitian "optimasi pemilihan investasi saham farmasi pada pandemic Covid-19, "sistem pendukung keputusan pemilihan pengrajin terbaik dalam pembuatan mabel atau prabot”(Saputro, 2020)(Sitorus \& Siregar, 2019)(Situmorang, 2015).

\section{METODOLOGI PENELITIAN}

\subsection{Investasi}

Investasi merupkan kegiatan, tindakan maupun sebuah upaya agar di masa depan dapat memperoleh sebuah keuntungan, investasi biasanya identik dan sangat berkaitan erat dengan masalah uang sebagai alat tukar di dalam setiap negara dan investasi diharapkan memberikan kebahagiana berupa laba untuk menghindari masalah-masalah maupun resiko yang tidak diharapkan baik secara personal maupun kelompok organisasi(Mahena, Rusli, \& Winarso, 2015).

Jenis dari investasi itu sendiri ada beberapa seperti investasi Properti, Rekas Dana, Emas, pendidikan (Skill) dan saham Investasi sering dikatakan sebagai menabung untuk masa depan lebih baik, beberapa alasan mengapa pentingnya melakukan investasi sebagai berikut:

1. Inflasi 
Inflasi merupakan sebuah kejadian dimana terjadinya penurunan terhadap mata uang tetapi mengalami kenaikan terhadap harga barang, setiap harga barang semakin meningkat secara terus menerus maka nilai mata uang akan ikut berpengaruh menjadi semakin rendah sehingga jika tidak melakukan investasi maka harta yang kita miliki tahun ini belum tentu akan bertahan di tahun pada masa kenaikan inflasi tersebut sehingga perlu dilakukan investasi agar harta yang kita miliki saat ini akan bertambah dan memiliki harga lebih baik bahkan tertinggi pada masa selanjutnya sehingga dapat disimpulkan bahwa kegiatan investasi dapat melawan dan membantu kesulitan Karena terjadinya inflasi.

2. Meraih mimpi dan menyelamatkan masa depan

Masa depan adalah yang tidak terduga akan ada beberapa masalah baik masalah dari faktor eksternal maupun internal yang akan dihadapi, baik buruknya masa depan dapat ditentukan dan masa depan yang cerah juga dapat ditentukan dengan melakukan investasi sebagai wacana atau alternatif lain yang dapat digunakan ketika masa-masa sulit sekalipun seperti dalam melakukan rencana pendidikan, masa tua dan lain-lain(Akmal \& Saputra, 2016).

\subsection{Risk Tolerance}

Risk tolerance merupakan penerapan ilmu dalam ilmu management resiko yang psikologi terhadap keadaan keuangan, resiko toleransi sangat mempengaruhi berbagai jenis keputusan dikarenakan seluruh orang yang memiliki uang pasti harus berhadapan dengan segala jenis kemungkinan yang terjadi dengan keuangannya dalam seluruh aktivitas keuangan, toleransi resiko ini dilihat dari jumlah resiko yang membuat seorang pemangku keuangan atau investor untuk merasa yakin akan keputusan untuk melakukan investasi(Chavali \& Mohanraj, 2016).

Resiko toleransi mendalami tentang kenyamanan seorang investor terhadap ketidakpastian terhadap kemampuan yang seorang investor dalam menentukan keputusan investasi, sikap toleransi ini kembali kepada kondisi dan situasi yang dihadapi. Dengan adanya risk tolerance ini menunjukan investor siap untuk menghadapi seluruh dampak negatif yang akan timbul untuk sampai pada tujuan yang ingin dicapai.

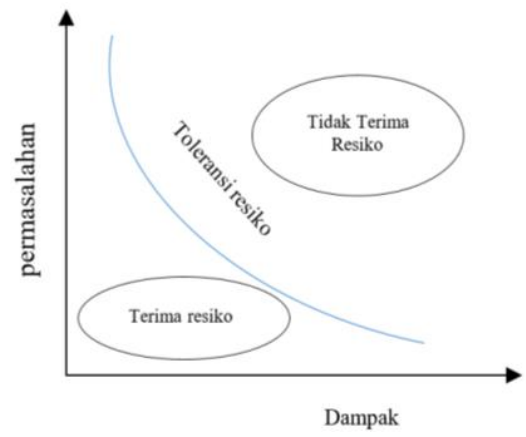

Gambar 1. Toleransi resiko

\subsection{Financial literacy}

Literatur finansial atau biasa disebut dengan literatur keuangan merupakan salah satu wajib ilmu yang harus diterapkan seluruh pengguna uang secara nyata untuk mengetahui informas terhadap keuangan dan pengendalian keuangan yang selama ini kita terapkan dalam kehidupan, financial literacy ini sangat berfungsi baik dalam kehidupan perusahaan baik baru.

Orang yang mampu memahami keuangannya dengan baik atau memiliki pengetahuan financial yang baik dapat dipastikan orang tersebut mengetahui atau memahami tentang literasi keuangan, fungsi dari literatur keuangan sendiri sebagai alat analisa untuk mengetahui dan mendapatkan informasi keuangan baik pribadi maupun milik perusahaan dengan hal tersebut dapat mempengaruhi keadaan dan kesejahteraan keuangan, membantu dalam managemen keuangan dengan baik dan Pada tahun 2019 literatur finansial bangsa Indonesia sebegsai 38,03\%(Setiawan Rifqi, 2020).

\subsection{Kemampuan Managemen Resiko}

Kemampuan managemen resiko sangat dibutuhkan oleh setiap individu bahkan seluruh kalangan, ketika mampu melakukan sebuah managemen resiko menunjukan keisapan, kesigapan dan keahlian seseorang terhadap hal-hal yang menjadi ancaman dalam, apapun jenis resiko tentu saja akan berdampak bersar baik secara personal maupun organisasi, sangat banyak perusahaan yang siap memberikan imbalan besar bagi pengolah resiko atau melakukan managemen resiko dari sebuah perusahaan(Buckl, Ernst, Matthes, Ramacher, \& Schweda, 2009)(Prabawa \& Lukiastuti, 2017).

kerangka kerja dari managemen resiko dimana secara sistematis saling berkaitan satu sama lain, sebagai berikut ini:

1. Identify Risk

dalam sebuah managmen resiko terlebih dahulu harus diketahui permasalahan yang akan dikenal untuk dapat diketahui tujuan vii misi,dan target apa yang akan dicapai.

2. Risk Assess and Analyze 
Untuk analisa terhadap berbagai jenis kemungkinan resiko baik besar atau resiko kecil serta dampak terjadinya resiko tersebut.

3. Plan Action

Melakukan perencanaan terhadap penyelesaian masalah dari identifikasi masalah sebelumnya.

4. Implement

Melakukan penerapan atau melaksanakan apa yang sudah direncanakan atau ditetapkan sebagai tujuan awal.

5. Measure, Control and Monitor

Adalah proses yg melibatkan langkah-langkah penyelesaian masalah,untuk memastikan, melihat apakah semua yang dituju dan direncanakan tidak terjadi kesalahan dan berjalan dengan baik.

setiap kegiatan menuju kepada strategi yang diterapkan untuk mencegah kemungkinan terburuk dari adanya dampak sebuah resiko baik resiko yang sedang tejadi maupun resiko yang masih diprediksikan akan terjadi dikarenakan beberapa faktor tertentu dalam sebuah perusahaan maupun instansi pemerintahan.

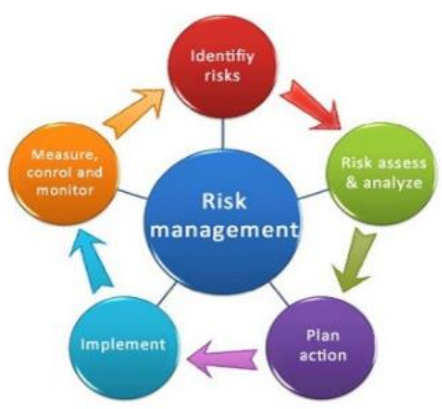

Gambar 2. Kerangka Kerja Managemen Resiko

\subsection{SAW (Simple Additive Weighting)}

SAW (Simple Additive Weighting) merupakan salah satu dari metode untuk membantu dalam masalah penentuan, pemilihan, pertimbangan dalam sebuah keputusan yang menghasilkan data berupa nilai dimana semakin tinggi nilai yang dihasilkan oleh data maka akan semakin jelas tingkat pengambilan keputusan yang dilakukan, dalam proses pengambilan keputusan dilakukan beberapa tahapan penyelesaian sebagai berikut ini(Irfan Fandinata \& Ginting, 2018)(Sitorus \& Siregar, 2019):

1. Menghitung Atribut nilai

$$
r_{i j}=\left\{\begin{array}{l}
\frac{x_{i j}}{\operatorname{Max} X_{i j}} \\
\frac{x_{i j}}{\operatorname{Max} X_{i j}}
\end{array}\right.
$$

2. Mencari Nilai Preference

$$
V_{i}=\sum_{j=1}^{n} w_{i} r_{i j}
$$

Keterangan:

$r_{i j}=$ rating kerja normalisai

$X_{i j}=$ nilai baris dan kolom

$V_{i j}=$ Nilai Akhir

$W_{j}=$ nilai pada bobot

$\operatorname{Max} X_{i j}=$ Nilai Maksimal pada matriks

$\operatorname{Min} X_{i j}=$ Nilai Minimum pada matriks

\section{HASIL DAN PEMBAHASAN}

Setiap kegiatan terhadap menentukan keputusan sangat penting mengetahui nilai terhadap setiap kriteria maupun faktor pendukung penunjang keputusan, dari data yang menjadi faktor pendukung pengambilan keputusan dalam investasi kecerdasan dan pengetahuan sangat penting untuk ada agar tidak melakukan kesalahan dan penyesalan pada akhirnya, setiap kegiatan investasi dapat dilakukan rekam jejak terhadap aktivitas yang dilakukan, pengambilan keputusan dalam investasi dapat digunakan dengan tahapan memanfaatkan kecanggihan teknologi dan kecerdasan manusia untuk mempermudah dalam melihat tingkatan ketergantungan terhadap setiap investasi dari kriteria-kriteria yang mempengaruhi dalam pengambilan keputusan investasi. Pada penelitian ini digunakan sebuah sistem pendukung keputusan untuk melihat tingkat keyakinan terhadap pengambilan keputusan dengan melihat nilai terhadap akumulasi keseluruhan data yang berpengaruh dalam keputusan investasi dengan menggunakan pendekatan pengambilan keputusan metode SAW (Simple Additive Weighting). 
Dalam pengambilan keputusan investasi akan dilihat berdasarkan tabel nilai dan hasil nilai perbandingan berdasarkan keseluruhan pengetahuan yang dimiliki dalam dunia investasi, investasi yang diambil berdasarkan kemampuan dari masingmasing investor yang diambil dari kriteria-kriteria yang telah ditetapkan dan berikut merupakan hasil dari penyelarasan menggunakan metode SAW. Pencarian keputusan terhadap keputusan investasi tentu memiliki kriteria pendukung dalam melihat seberapa besar presentasi terhadap kemampuan melakukan investasi dalam hal ini investasi yang akan dilakukan merupakan investasi terhadap jenis investasi dengan melihat kapasitas dan kemampuan terhadap investor dalam memilih dan menempatkan diri terhadap investasi.

Tabel 1. Kriteria dan Bobot

\begin{tabular}{cccc}
\hline Kode & Kriteria & Bobot & Jenis \\
\hline C1 & Literatur Keuangan & 0,45 & Benefit \\
C2 & Resiko Toleransi & 0,2 & Benefit \\
C3 & Managemen resiko & 0,35 & Benefit \\
\hline
\end{tabular}

Adapun jenis investasi sebagai berikut ini:

1. Saham

Saham merupakan sebuah bagian atau dapat dianalogikan sebagai kepemilikan dari beberapa modal awal sebuah bisnis atau kepemilikan beberapa persen atau seberapa bagian dalam bukti kepemilikan nilai Perusahaan

2. Obligasi

Obligasi merupakan sebuah bukti berupa surat maupun sertifikat yang memiliki nilai yang sangat berharga.

3. Deposito

Deposito merupakan salah satu cara menabung disimpan dalam bentuk rekening tabungan yang tidak boleh dicairkan sebelum tanggal yang telah ditentukan, hampir sama dengan menabung biasa, tetapi masa penarikan uang yang berbeda.

4. Valuta Asing

Merupakan tabungan berupa atau jenis perdagangan dalam pengumpulan mata uang asing, pada investasi ini memanfaatkan terhadap aktivitas kurs baik rendah maupun tinggi, biasanya dilakukan penjualan ketika harga mata uang asing sedang sangat tinggi.

5. Reksadana Pasar Uang

Berhubungan dengan mengolah investasi Obligasi, Deposito, Sertifikasi berharga contoh sertifikat Bank Indonesia, yang sedang mengalami jatuh tempo dan biasanya dilakukan penjualan dan penawaran harga lebih tinggi.

6. Reksadana Pendapatan Tetap

Reksadana jenis inilebih kepada efek hutang

7. Reksadana Saham

8. Emas

Melakukan pembelian emas dan melakukan penjualan kembali ketika harga emas kembali naik

9. Properti

Property berupa barang-barang berharga seperti rumah seperti rumah sewa rumah pribadi, penyewaan dan lain-lain.

10. Pendidikan

Pendidikan merupakan pilihan investasi terbaik, pendidikan memang memerlukan biaya yang cukup besar tetapi dengan adanya pendidikan seseorang dapat berinvestasi dengan kehidupan masa depan.

Lakukan pertihutang mengunakan metode SAW dengan cara sebagai berikut ini:

1. Tentukan alternatif, kriteria dan bobot yang sesuai dengan yang ingin dilakukan pengujian

2. Membuat matriks Normalisasi

3. Mencari nilai Atribut dengan cara melihat terlebih dahulu jenis kriteria merupakan benefit atau bernilai cost agar dapat ditentukan rumus mana yang akan digunakan, jika itu bernilai benefit maka nilai dari setiap kriteria dibagi dengan nilai tertinggi dari keseluruhan nilai sabuah kriteria dan lakukan keseluruh kriteria.

4. Mencari nilai Preference, setelah mendapatkan nilai masing-masing Atribut lakukan perkalian dengan masing-maisng bobot yang terlah ditentukan sebelumnya seteah itu jumlahkan nilai masing-masing alteratif terhadap kriteria yang dimiliki

5. Pada nilai tertinggi merupakan kemungkinan terhadap melakukan investasi, jika nilaibernilai paing tertinggi maka keputusan investasi semakin matang dan semakin menunjukan kemampuan terhadap literature keuangan dan kondisi keuangannya serta kemampuan dalam keseluruhan resiko yang akan dikelola semakin tinggi, semakin rendah kemampuan investasi maka dapat melakukan investasi yang memiliki resiko dan literature terhadap keuangan yang minim tetapi masih dapat melakukan investasi. 
Ekonomi, Keuangan, Investasi dan Syariah (EKUITAS)

Vol 2, No 2, Februari 2021, Hal 170-176

ISSN 2685-869X (media online)

DOI: $10.47065 /$ ekuitas.v2i2.660

Tabel 2. Hasil pencarian Nilai

\begin{tabular}{lcccc}
\hline \multicolumn{1}{c}{ Alternatif } & C1 & C2 & C3 & Hasil \\
\hline Saham & 0,45 & 0,15 & 0,0875 & 0,6875 \\
Obligasi & 0,1125 & 0,15 & 0,35 & 0,6125 \\
Deposito & 0,1125 & 0,2 & 0,2625 & 0,575 \\
Valuta Asing & 0,1125 & 0,1 & 0,175 & 0,3875 \\
Reksadana Pasar Uang & 0,45 & 0,1 & 0,0875 & 0,6375 \\
Reksadana Pendapatan Tetap & 0,45 & 0,1 & 0,175 & 0,725 \\
Emas & 0,05625 & 0,1 & 0,35 & 0,50625 \\
Reksadana Saham & 0,3375 & 0,2 & 0,35 & 0,8875 \\
Properti & 0,225 & 0,15 & 0,04375 & 0,41875 \\
Pendidikan & 0,1125 & 0,05 & 0,2625 & 0,425 \\
\hline
\end{tabular}

Tabel 2 merupakan table hasil dari akumulasi perhitungan dari bebrapa kriteria yang tertera, dalam hasil diatas merupakan hasil dari penggunaan metode SAW dimana setiap nilai yang dimiliki merupakan nilai yang telah ditetapkan berdasarkan kriteria, hasil akan menunjukan kepada investasi mana seorang investor dapat memilih jenis investasinya, jenis investasi mana yang dapat ditetapkan dengan mengukur kriteria kemampuan yang telah dianalisa, setelah diketahui nilai tersebut menunjukan sangat membantu investor dalam mengukur data alternatif mana juga yang dimiliki.

\section{KESIMPULAN}

Nilai tertinggi memperlihatkan hasil sampai $88 \%$ tingkat keyakinan dalam keputusan investasi tertinggi ada pada alternatif investasi "Saham" dan pada investasi yang lain memiliki tingkat mengambil keputusan investasi berbeda-beda semakin tinggi nilai yang didapat maka hasil menunjukan semakin baik akan pengetahuan dan faktor pendukung terhadap keberanian dalam investasi dan ilmu investasi yang diharapkan. Seorang investor harus memiliki pengetahuan terhadap kondisi keuangan atau literatur keuangan untuk dapat mendukung pengetahuan terhadap kemampuan investasi dari keuangannya, seorang investor juga harus memiliki kemampuan terhadap pengetahuan resiko toleransi jika terjadi sesuatu hal yang berdampak kepada investasinya dan mampu mengolah resiko tersebut ataupun melakukan analisa terhadap resiko untuk mengurangi kejadian yang tidak di inginkan dan penggunaan metode simple additive weighting mempermudah pengambilan keputusan investasi.

\section{DAFTAR PUSTAKA}

Akmal, H., \& Saputra, Y. E. K. A. (2016). Analisis tingkat literasi keuangan. Jebi (Jurnal Ekonomi Dan Bisnis Islam), 1(2), $235-244$.

Babar, S., Thaheem, M. J., \& Ayub, B. (2017). Estimated cost at completion: Integrating risk into earned value management. Journal of Construction Engineering and Management, 143(3). https://doi.org/10.1061/(ASCE)CO.1943-7862.0001245

Bellini, F., \& Di Bernardino, E. (2017). Risk management with expectiles. European Journal of Finance, $23(6), 487-506$. https://doi.org/10.1080/1351847X.2015.1052150

Buckl, S., Ernst, A. M., Matthes, F., Ramacher, R., \& Schweda, C. M. (2009). Enterprise Architecture based on Design Primitives and Patterns: Guidelines for the Design of Business Process Models (DoDAF OV-6c) using BPMN. Enterprise Distributed Object Computing Conference, 2009. EDOC'09. IEEE International, 34-41.

Chavali, K., \& Mohanraj, M. P. (2016). Impact of demographic variables and risk tolerance on investment decisions: An empirical analysis. International Journal of Economics and Financial Issues, 6(1), 169-175.

Gede Rudangga, I., \& Merta Sudiarta, G. (2016). Pengaruh Ukuran Perusahaan, Leverage, Dan Profitabilitas Terhadap Nilai Perusahaan. E-Jurnal Manajemen Universitas Udayana, 5(7).

Irfan Fandinata, B. S., \& Ginting. (2018). Sistem Pendukung Keputusan Pemilihan Bibit Mangga Terunggul Menerapkan Metode SAW dan WASPAS. 2(1), 27-36.

Mahena, Y., Rusli, M., \& Winarso, E. (2015). Prediksi Harga Emas Dunia Sebagai Pendukung Keputusan Investasi Saham Emas Menggunakan Teknik Data Mining. Kalbiscentia Jurnal Sains Dan Teknologi, 2(1), 36-51.

Prabawa, D. W., \& Lukiastuti, F. (2017). Analisis Pengaruh Kinerja Keuangan, Manajemen Risiko Dan Manajemen Modal Kerja Terhadap Return Saham. Jurnal Manajemen Indonesia, 15(1), 1. https://doi.org/10.25124/jmi.v15i1.388

Robo, S., Trisno, T., Sunardi, S., \& Santosa, S. (2019). Analisis Implementasi Sistem Informasi Keuangan, Kompetensi Pegawai dan Evaluasi Manajemen Terhadap Efektifitas Pengelolaan Keuangan Pada Unit Program Belajar Jarak Jauh Universitas Terbuka Seluruh. 10(1), 35-43. https://doi.org/10.32832/jm-uika.v10i1.1893

Saputro, S. H. (2020). Optimasi Pemilihan Investasi Saham Farmasi Dengan Metode Key Statistics Fundamental Pada Pandemi Covid-19. Jaman, 1(1), 104-109.

Setiawan Rifqi, A. (2020). Lembar Kegiatan Literasi Saintik untuk Pembelajaran Jarak Jauh Topik Penyakit Coronavirus 2019 (COVID19). Jurnal Ilmu Pendidikan, 2(1), 28-37.

Sitorus, S., \& Siregar, K. (2019). Sistem Pendukung Keputusan Pemilihan Pengrajin Terbaik Dalam Pembuatan Mebel Atau Prabot Di Cv. Metro Prabot Menggunakan Metode Simple Additive Weighting (Saw). Jurnal Pelita Informatika, 18(2), $179-185$.

Situmorang, H. (2015). Olimpiade Sains Tingkat Kabupaten Langkat Pada Madrasah Aliyah Negeri ( Man ) 2 Tanjung Pura Denganmenggunakan Metode Simple Additive Weighting ( Saw ). IV(2), 24-30.

Yunaldi, A. (2019). Sistem Pendukung Keputusan Seleksi Bantuan Siswa Miskin Menerapkan Kombinasi Metode SAW dan ROC. Jurnal 
Ekonomi, Keuangan, Investasi dan Syariah (EKUITAS)

Vol 2, No 2, Februari 2021, Hal 170-176

ISSN 2685-869X (media online)

DOI: $10.47065 /$ ekuitas.v2i2.660

Media Informatika Budidarma, 3(4), 376. https://doi.org/10.30865/mib.v3i4.1511

Yunita Wulan Dewi, N. K., \& Sri Darma, G. (2019). Strategi Investasi \& Manajemen Resiko Rumah Sakit Swasta di Bali. Jurnal Manajemen Bisnis, 16(2), 110. https://doi.org/10.38043/jmb.v16i2.2044

Yushita, A. N. (2017). Pentingnya Literasi Keuangan Bagi Pengelolaan Keuangan Pribadi. Nominal, Barometer Riset Akuntansi Dan Manajemen, 6(1). https://doi.org/10.21831/nominal.v6i1.14330 